\title{
PELATIHAN PEMBUATAN YOGHURT BAGI KELOMPOK USAHA PENGOLAH SUSU SAPI BOYOLALI
}

\author{
Harianingsih ${ }^{1 *}$, Suwardiyono ${ }^{2}$ \\ ${ }^{1}$ Jurusan Teknik Kimia, Fakultas Teknik, Universitas Negeri Semarang \\ Kampus Sekaran, Gunungpati, Semarang 50229 \\ ${ }^{2}$ Jurusan Teknik Kimia, Fakultas Teknik, Universitas Wahid Hasyim \\ Jl. Menoreh Tengah X/22, Sampangan, Semarang 50236. \\ "Email: harianingsih3@gmail.com
}

\begin{abstract}
Abstrak
Kabupaten Boyolali merupakan daerah penghasil susu sapi yang menopang kebutuhan susu sapi di wilayah Jawa Tengah. Perkembangan industry susu ternyata tidak berbanding lurus dengan tingkat kesejahteraan masyarakat kabupaten Boyolali yang kesehariannnya bekerja sebagai peternak atau pemerah susu. Harga susu segar yang murah tidak dapat menutup kebutuhan pangan sapi. Untuk itu diperlukan solusi diversifikasi susu sgar menjadi produk yoghurt agar harga susu segar yang awalnya murah dapat lebih tinggi. Inovasi yang digunakan adalah teknologi fermentasi yang dapat dilakukan di rumah dan dengan cara sederhana tapi tetap kualitas terjaga dengan baik tidak kalah dengan produk yoghurt yang ada di pasaran. Metode yang dilakukan berupa observasi mitra, persiapan, pelatihan motivasi kewirausahaan, dan pelatihan pembuatan yoghurt. Hasil Pelaksanaan kegiatan antara lain, peserta yang hadir sejumlah 20 orang yang berasal dari dua kelompok usaha pengolah susu sapi. Yoghurt yang dihasilkan disesuaikan dengan permintaan pasar dan disukai oleh anak-anak sampai orang dewasa dengan berbagai variasi rasa. Rasa yang terdapat pada yoghurt antara lain rasa strawberry, rasa anggur dan rasa lecy serta ada plan yoghurt (tanpa rasa).
\end{abstract}

Kata kunci: boyolali, susu sapi, yoghurt

\section{PENDAHULUAN}

Kabupaten Boyolali merupakan penopang kebutuhan Industri Pengolahan Susu (IPS) propinsi Jawa Tengah. Distribusi susu dari Boyolali meliputi daerah kabupaten Boyolali itu sendiri, Semarang, Klaten dan Solo. Proses Pemasaran susu sapi di Kabupaten Boyolali dikelola oleh Koperasi Unit Desa (KUD) yang kemudian disetorkan pada industri susu instant. KUD memiliki patokan harga susu yang jauh dari kisaran layak. Hasil wawancara dengan ketua kelompok usaha pengolah susu desa Pengging Bapak Supardi dan Bapak Rohman, bahwasanya kisaran harga susu pada tahun 2017 ini sebesar Rp. 2.700 - Rp. 3.000 per liter. Sementara harga yang layak untuk saat ini berkisar anatara Rp.5.000 - Rp. 6.000. Harga patokan yang diberikan KUD setempat tidak sebanding dan belum menutup harga pakan ternak. Rata - rata satu ekor sapi membutuhkan 50 kilogram ampas tahu, 2 kilogram konsentrat dan 2 kilogram bekatul serta rumput atau makanan hijau yang lainnya. Sehingga biaya pakan minimal yang dibutuhkan adalah Rp. 25.000 per ekor sapi. Produksi susu per hari rata-rata sebanyak 5-7 liter dan jika dijual hanya diperoleh Rp.15.000- Rp. 21.000 .

Standar kualitas susu yang diambil oleh KUD juga telah ditetapkan. KUD melakukan uji parameter kualitas susu yang memnyebabkan banyak susu dari peternak sapi tidak diterima untuk didistribusikan. Hal ini karena pada kelompok usaha pengolah susu sapi menampung hasil panen susunya terlebih dahulu, setelah hasil melimpah baru disetor ke KUD. Banyak susu yang disetor tidak layak akhirnya hanya dibuang ke sungai di lingkungan sekitar. Pembuangan ini menyebabgkan lingkungan menjadi tidak sehat dan bau tidak sedap (Rahman, 2013). 
Kelompok usaha pengolah susu sapi Bapak Supardi dan Bapak Rohman memiliki anggota yang terdiri dari 10 orang dengan jumlah sapi 6 ekor per kelompok. Awalnya mereka merupakan pengolah susu sapi yang produktif. Akan tetapi karena alas an di atas usaha pengolahan susu sapi berubah menjadi ternak sapi peranakan. Potensi susu sapi pada kelompok pengolah susu sapi ini sangat disayangkan. Untuk itu tim pengabdian masyarakat memberikan solusi terhadap permasalahan yang dialami kelompok usaha pengolah susu sapi yang dipimpin oleh Bapak Supardi dan Bapak Rohman dengan memberikan pelatihan berupa diversifikasi susu sapi menjadi Yoghurt. Harapan dari pelatihan pembuatan Yoghurt yang sehat dan mempunyai nilai jual lebih tinggi serta daya simpan lebih lama dapat meningkatkan ekonomi para anggota kelompok usaha pengolah susu sapi.

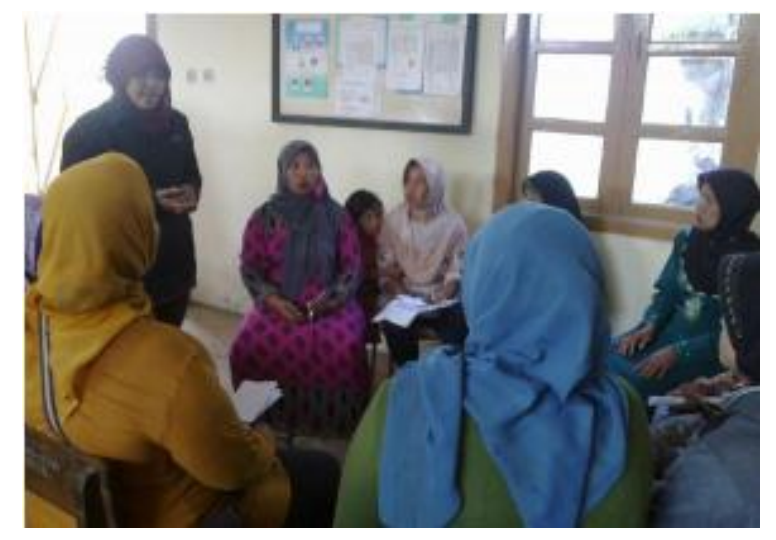

\section{Gambar 1. Observasi Permasalahan Mitra}

Yogurt adalah salah satu produk susu terkoagulasi (mengental), diperoleh dari fermentasi asam laktat melalui aktifitas bakteri Lactobacillus delbrueckii var. bulgaricus dan Streptococcus salivarus var. thermophillus, dimana mikroorganisme ini dalam produk akhir harus hidup aktif dan berlimpah (Ratnawati dkk, 2015). Manfaat yoghurt bagi kesehatan antara lain, memproduksi vitamin, meningkatkan nilai gizi dan membantu pertumbuhan. Saat proses fermentasi, terjadi kenaikan kadar vitamin-vitamin sebagai hasil kerja bakteri, yaitu A, B2, B3, biotin, dan asam folat (Pusbangtepa, 2012). Menurut Rangkuti (2015), yogurt juga mengandung asam amino yang tinggi sebagai hasil kerja bakteri. Bakteri yogurt juga mampu mensintesis beberapa vitamin seperti riboflavin dan niacin serta thiamin. Mineral dalam yogurt meskipun tidak bertambah banyak, tapi menjadi lebih mudah untuk diserap tubuh.

Memproduksi antibiotik dalam melawan virus dan jamur. Lactobacillus bulgaricus, mampu menghasilkan zat antibiotika yang disebut bulgarikan. Zat ini berbeda dengan antibiotik yang biasa kita kenal. Antibiotik ini kerjanya lebih spesifik pada mikroorganisme yang merugikan saja sehingga berefek menguntungkan bagi kita. Menurunkan kolesterol, kemampuan ini berasal dari zat factor antikolesterol yang menghambat kerja enzim pembentuk kolesterol. Pengurangan kolesterol juga terjadi karena selama pertumbuhan bakteri menyerap sejumlah zat kolesterol ke dalam selnya. Penyerapan ini terjadi di usus kecil dan membantu mengurangi kolesterol dalam darah (fatmawati dkk, 2015).

Memerangi kanker dan tumor, serta meningkatkan kekebalan tubuh. Bakteri asam laktat dalam usus besar mampu menyerap zat mutagenic dari makanan. Berarti dengan meminum atau memakan yogurt secara teratur dapat membantu mencegah kanker usus. Ketika "diadukan" langsung (dioleskan) dengan sel tumor, yogurt, susu acidophilus, susu 
bifidus, atau susu casei (susu L.casei contohnya adalah Yakult) dapat menghambat pertumbuhan sel tumor. Di samping itu zat tertentu yang diambil dari dinding sel bakteri bifidus dan L. bulgaricus juga memiliki efek antitumor dan dapat meningkatkan kekebalan tubuh terhadap tumor. Oleh sebab itu pengolahan susu segar menjadi yoghurt sangat potensial untuk memenuhi kebutuhan masyarakat akan protein hewani dan menunjang kesehatan.

\section{METODE}

Metode pengabdian masyarakat yang digunakan antara lain menggunakan Tahapan pelaksanaan pelatihan pembuatan yoghurt pada kelompok usaha pengolah susu sapi antara lain:

1. Tahap Persiapan

Pada tahap ini akan dilaksanakan Observasi lokasi, sosialisasi, koordinasi kepada mitra, pengurusan ijin kegiatan, dan pembelian serta perancangan peralatan .

2. Tahap Pelatihan

Metode yang digunakan pada tahap ini sebagai berikut

a. Memberikan penyuluhan tentang potensi susu sapi yang saat ini dihentikan proses pemerahannya oleh kelompok usaha pengolah susu sapi mitra dikarenakan harga jual susu sapi yang diambil KUD tidak menutup biaya pakan. Penyuluhan diberikan saat sosialisasi dengan memotivasi agar mitra dapat melanjutkan produksi susu sapinya. Inovasi diversifikasi olahan susu sapi menjadi yoghurt yang mempunyai nilai ekonomi tinggi. Metode yang digunakan berupa presentasi, diskusi dan tanya jawab. Penyuluhan diberikan agar mitra mengetahui dengan benar manfaat dari pelatihan sehingga dapat diaplikasikan dengan baik.

b. Pelatihan motivasi wirausaha diberikan guna membuka pikiran mitra akan jiwa kewirausahaan. Anggota mitra rata-rata berasal dari latar belakang petani dan peternak

c. Pelatihan Pembuatan Yoghurt

Pembuatan yoghurt memerlukan bahan dan alat sebagai berikut tiap 1 liter susu yaitu: gula pasir $250 \mathrm{~g}$, bibit yogurt plain $3 \mathrm{sdm}$ (bisa diperoleh di took/minimarket), essence buah secukupnya, penstabil nabati (CMC) 1 sdt. Adapun alat yang dipakai dalam pembuatan yoghurt yaitu: panci pemanas susu untuk mempasteurisasi susu, toples palastik, penyaring, pengaduk, incubator, cup kemasan, ice box, dan lemari pendingin. Langkah pembuatan yogurt susu adalah sebagai berikut: pertama susu sapi disaring agar terhindar dari kotoran, kemudian dipanaskan selama 15 menit dan tidak sampai mendidih (pasteurisasi) dalam panci heater. Setelah proses pasteurisasi, susu dinginkan hingga suhu $40-45^{\circ} \mathrm{C}$ dengan merendam panci pada air dingin. Sebanyak $200 \mathrm{~g}(4 \mathrm{sdm})$ bibit yoghurt ditambahkan dan diaduk rata. Yoghurt diinkubasi pada suhu $40-45{ }^{\circ} \mathrm{C}$ selama 5-6 jam atau suhu ruang selama 12 jam dengan menggunakan panci inkubator. Setelah diinkubasi, tambahkan gula pasir sebanyak $250 \mathrm{~g}$ dan essence buah secukupnya dan kemudian aduk rata.

\section{HASIL DAN PEMBAHASAN}

Pelaksanaan pelatihan pembuatan yoghurt dilaksanakan pada dua kelompok usaha pengolah susu sapi yang terdiri dari 10 orang tiap kelompok. Peserta pelatihan sebanyak 20 orang tersebut merupakan ibu-ibu yang di tempat tinggalnya memiliki dan memelihara ternak sapi perah antara 1-6 ekor atau buruh pemerah sapi milik Bapak Supardi dan Bapak Rohman. 
Motivasi kewirausahaan bertujuan untuk mengajak peserta mempunyai keinginan untuk tidak ada keraguan untuk memproduksi yoghurt skala rumah tangga dan dapat melihat peluang pemasaran dari yoghurt tersebut. Peserta sangat antusias dan terbuka pola pemikirannya. Hal ini diperlukan karena peserta berasal dari desa yang kesehariannya bertani dan berternak sapi. Dokumentasi selama pelatihan dapat dilihat pada gambar 1, 2 dan 3 .

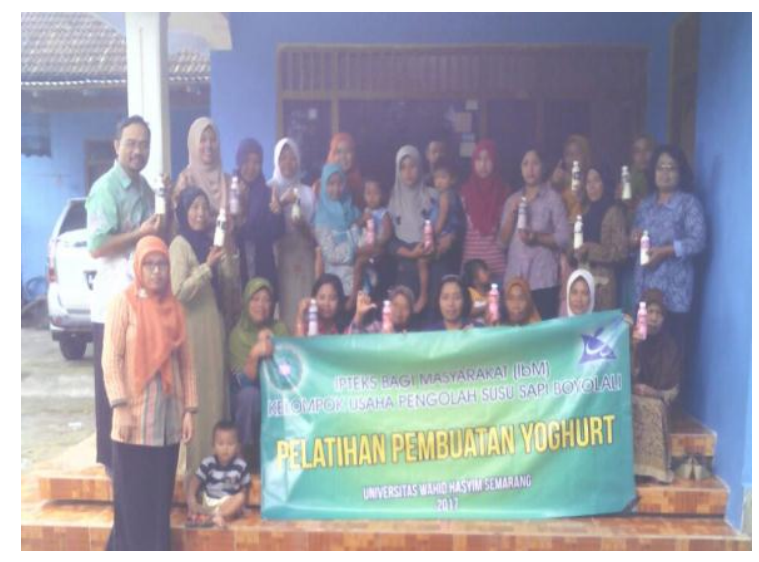

\section{Gambar 1. Peserta Pelatihan Pembuatan Yoghurt}

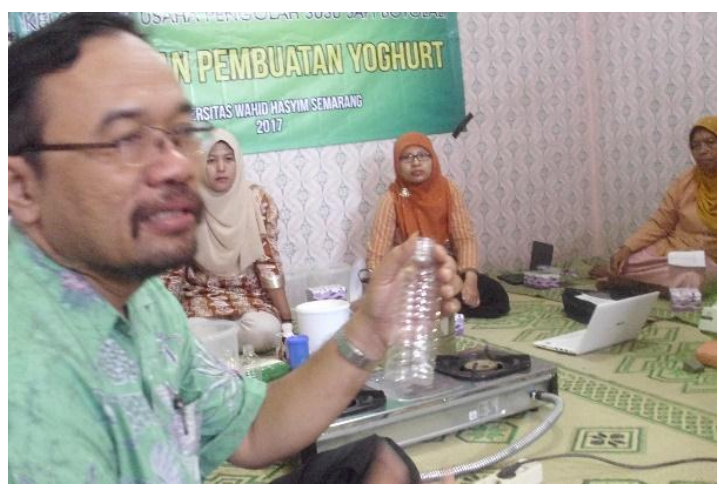

Gambar 2. Pelatihan Motivasi Kewirausahaan

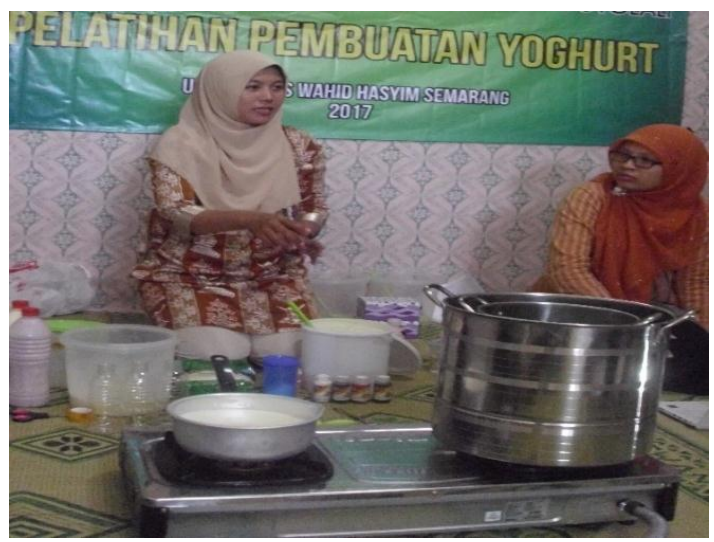

Gambar 3. Demonstrasi Pembuatan Yoghurt

Pelatihan pembuatan yoghurt dipresentasikan dengan metode secara sederhana agar mudah dipahami oleh peserta berupa praktek/ demonstrasi, diskusi dan tanya jawab. Pada 
saat pelatihan pembuatan yoghurt dijelaskan juga manfaat, cara pembuatan serta cara penyimpanan.

Pada tahap selanjutnya diharapkan bentuk kegiatan kemitraan dengan pelatihan pembuatan yoghurt ini adalah peserta dapat menyampaikan teknologi fermentasi diversifikasi olahan susu segar menjadi yoghurt kepada pengolah susu yang lain yang tidak ikut dalam pelatihan. Bahasa yang digunakan tentu saja akan lebih mudah diterima oleh peternak yang lain. Hal ini dipengaruhi sifat umum pengolah/ peternak susu sapi yang lebih mudah menerima dan percaya pada teknologi baru melalui peternak lain yang sudah pernah melakukannya.

Pada tahapan pembuatan yoghurt peserta aktif dan melakukan diskusi tanya jawab seputar tips-tips agar yoghurt yang dibuat berhasil. Adapun parstisipasi dari mitra adalah menyediakan susu segar sebagai bahan baku pembuatan yoghurt. Transfer iptek berupa sentuhan teknologi fermentasi susu segar menjadi suatu produk baru dengan berbagai rasa serta efek kesehatan yang baik dapat diterima oleh peserta. Pada pembuatan yoghurt diperlukan stater atau bibit yoghurt. Peserta dapat memperbanyak stater sendiri. Stater yang asli (plan yoghurt) dapat dibeli secara online, akan tetapi jika peserta mengalami kesulitan dalam pembelian stater dapat digunakan yakult yang ada di pasaran. Proses pemanasan atau pasteurisasi juga harus dilakukan dengan cermat. Pemanasan dilakukan pada suhu $70^{\circ} \mathrm{C}$ agar tidak mengalami kerusakan atau penggumpalan. Pasterurisasi dilakukan menggunakan panci yang terdiri dari 2 tingkat, panci yang pertama fungsinya sebagai waterbath, tempat air sedangkan panci di dalamnya digunakan untuk pasteurisasi susu. Fermentasi dilakukan selama 8 jam pada ruang tertutup. Pada pelatihan ini digunakan cooler sebagai media inkubasi fermentasi. Cooler mempunyai karakter dapat mempertahankan suhu fermentasi. Proses inkubasi berlangsung pada suhu $40-45{ }^{\circ} \mathrm{C}$. Yoghurt harus disimpan di lemari es $\left(\right.$ suhu $-6^{\circ} \mathrm{C}$ ) untuk menjaga agar tidak cepat basi, karena sifat dari susu yang mudah mengalami kebasian. Yoghurt tidak diberi bahan pengawet karena dikonsumsi oleh anak-anak sampai orang dewasa yang berpengaruh juga terhadap kesehatan.

Indikator pelaksanaan kegiatan disajikan pada tabel 1. Indikator terdiri dari sasaran dan keluaran dari pelaksanaan pengabdian masyarakat.

Tabel 1. Hasil Pelaksanaan Pelatihan Pembuatan Yoghurt di Desa Pengging

\begin{tabular}{|c|c|c|c|}
\hline Indika-tor & Uraian & Rencana/ Target & Realisasi \\
\hline \multirow[t]{4}{*}{ Sasaran (Goal) } & $\begin{array}{l}\text { Jumlah } \\
\text { Kegiatan }\end{array}$ & 20 orang & 20 orang \\
\hline & $\begin{array}{l}\text { Pemberda-yaan } \\
\text { masyara-kat }\end{array}$ & $\begin{array}{l}\text { Kelom-pok usaha } \\
\text { pengolah susu sapi } \\
\text { desa Pengging }\end{array}$ & $\begin{array}{l}\text { Kelom-pok usaha } \\
\text { pengolah susu sapi desa } \\
\text { Pengging }\end{array}$ \\
\hline & $\begin{array}{l}\text { Jenis Kelamin } \\
\text { Peserta Kegiatan }\end{array}$ & $\begin{array}{l}10 \text { laki-laki } \\
10 \text { wanita }\end{array}$ & $\begin{array}{l}1 \text { laki-laki } \\
19 \text { wanita }\end{array}$ \\
\hline & $\begin{array}{l}\text { Berkembangnya } \\
\text { produktivitas home } \\
\text { industri yoghurt }\end{array}$ & $\begin{array}{lr}\text { Adanya } & \text { respon } \\
\text { positif dan } & \text { kemauan } \\
\text { untuk } & \text { mengem- } \\
\text { bangkan } & \text { produk } \\
\text { yoghurt } & \\
\end{array}$ & $\begin{array}{l}\text { Baru uji coba produksi } \\
\text { yoghurt home industri }\end{array}$ \\
\hline $\begin{array}{l}\text { Keluar-an } \\
\text { (Output) }\end{array}$ & $\begin{array}{l}\text { Pemberi-an motivasi } \\
\text { kewirausahaan }\end{array}$ & $\begin{array}{l}\text { Memahami tujuan } \\
\text { dari wirausaha } \\
\text { produksi yoghurt }\end{array}$ & $\begin{array}{l}\text { Peserta memahami dan } \\
\text { mempun-yai motivasi } \\
\text { untuk wirausa-ha } \\
\text { yoghurt }\end{array}$ \\
\hline
\end{tabular}




\begin{tabular}{|l|l|l|lr|}
\hline \hline & $\begin{array}{l}\text { Pelatihan Pembuat- } \\
\text { an Yoghurt }\end{array}$ & $\begin{array}{l}\text { Transfer IPTEK } \\
\text { bagaima-na } \\
\text { pengolah-an susu } \\
\text { sapi menjadi yoghurt }\end{array}$ & $\begin{array}{l}\text { Peserta memahami } \\
\text { tujuan dan cara } \\
\text { pembuat-an yoghurt }\end{array}$ \\
\hline
\end{tabular}

Pada tabel 1 dapat diketahui bahwa semua kegiatan yang direncanakan dapat direalisasikan dengan baik dan memenuhi target yang diharapkan. Hal ini menunjukkan bahwa kegiatan pelatihan pembuatan yoghurt merupakan kegiatan yang dapat direferensikan sebagai solusi permasalahan kelompok pengolah susu sapi, yang saat ini sedang mengalami penurunan pendapatan bahkan tidak memerah sapinya lagi karena harga susu sapi yang sangat rendah (Rp.2.700,00-Rp. 3.000,000 per liter).

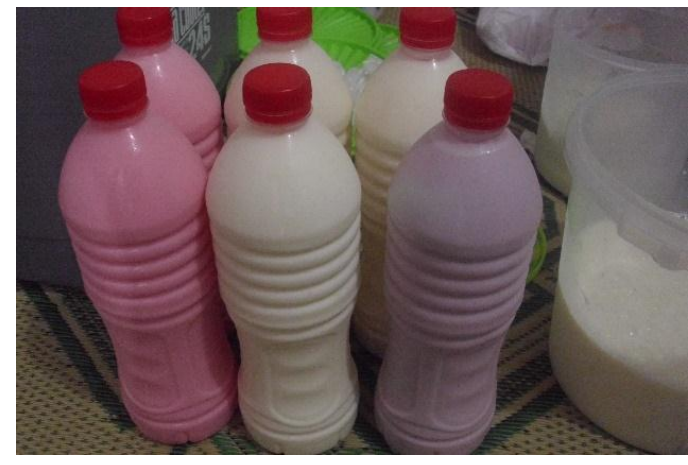

\section{Gambar 4. Yoghurt berbagai rasa hasil pelatihan}

Peserta pelatihan mengungkapkan sangat antusias dan ingin mengembangkan diversifikasi olahan susu ini untuk dapat dijadikan sebagai home industri. Pembuatan yoghurt dibuat dengan melihat selera pasar dengan berbagai variasi rasa yang disukai konsumen dari anak-anak sampai dewasa, seperti rasa strawbery, rasa lecy, rasa anggur dan bagi yang menginginkan yoghurt tanpa rasa ada juga plan yoghurt.

\section{KESIMPULAN}

Pelatihan pembuatan yoghurt bagi kelompok usaha pengolah susu sapi dilaksanakan dengan baik dan tepat dilakukan pada mitra sebagai solusi diversifikasi dan inovasi produk olahan susu segar. Pendapatan mitra akan meningkat jika program pelatihan ini dapat ditindaklanjuti menjadi suatu usaha skala rumah tangga. Kemampuan SDM mitra bertambah dengan adanya transfer IPTEK pelatihan pembuatan yoghurt. Yoghurt yang diproduksi disesuaikan dengan permintaan pasar dengan berbagai varian rasa dan menunjang kesehatan.

Perlu adanya pelatihan lanjutan untuk pemasaran dan observasi daerah pemasaran di sekitar wilayah mitra agar program pengabdian masyarakat tidak hanya berhenti pada proses pelatihan pembuatan yoghurt saja.

Adanya pendampingan untuk proses perijinan PIRT untuk bahan makanan pada instansi terkait.

\section{DAFTAR PUSTAKA}

Fatmawati, Umi., Rinanto, Yudi., dan Maya, Harlita., 2015, Pemberdayaan Kelompok Tani Susu Melalui Pelatihan Pengolahan Produk Makanan Berbahan Dasar Susu dalam Rangka Peningkatan Nilai Ekonomi Susu, Prosiding UMS, pp. 123-135.

Pusbangtepa, 2012, Pembuatan Yoghurt, Jurnal Tekno Pangan dan Agroindustri, 1(12). Pp. 23-29. 
Rahman, Syamsul., dan Rauf, Awaluddin., 2013, IbM Kelompok Usaha Sapi Perah dan Pengolahan Dangke di Kabupaten Enrekang, Majalah Aplikasi Ipteks Ngayah, 4(1), pp. 48-62.

Rangkuti, Khairunnisa., 2015, IbM Kelompok Ternak Sapi Pembuatan Yoghurt dari Susu Sapi Skala Rumah Tangga, Prosiding UMS, pp. 1-6.

Ratnawati., Astuti., dan Suhandono., 2015, Peningkatan Pendapatan Masyarakat Dusun Gading Cangkringan Sleman DIY Melalui Penyuluhan Pembuatan Yoghurt Aneka Rasa, Inotek, 19(1), pp. 87-94. 